\title{
Merdivenli Sokaklarda Sosyal Mekân Oluşumuna Etki Eden Unsurlar ve İstanbul'dan Üç Örnek İçin Değerlendirme
}

\author{
İlke Ciritci ${ }^{1}$ \\ ORCID: 0000-0002-1492-0727
}

*

\author{
Gül Yücel ${ }^{2}$ \\ ORCID: 0000-0003-3722-6479
}

Öz

Çalışmada merdivenli sokaklarda sosyal mekân oluşum potansiyeli ve buna etki eden unsurlar tartışılmıştır. Çalışma kapsamında sokak, merdivenli sokak, sosyal mekân, kamusal alan, aidiyet kavramlar mimarlık literatüründe araştırlmış, kentle ilişkilendirilerek, kavramsal bağlar kurulması amaçlanmıştır. Dünyanın birçok kentinde ziyaret edilen popüler merdivenli sokaklar olduğu gibi, İstanbul'un tarihi bölgelerinde de ilgi çeken merdivenli sokaklar bulunmaktadır. Nitel araştırma yöntemi ile merdivenli sokaklarn kamusal alan kullanımı ulaşılabilirlik, konfor, etkinlik ve estetik parametreleri üzerinden incelenmiş, bu kapsamda sosyal mekân olarak kullanım başarısı, merdivenlerin potansiyelleri, yerinde gözlem ve ölçüm yöntemleri ile tespit edilmiştir. Çalışma kapsaminda İstanbul tarihi yerleşim alanlarında bulunan merdivenli sokaklardan Balat Merdivenli Mektep Sokak, Beyoğlu Hacı Ali Sokak ve Üsküdar Yeni Dünya Sokak fiziksel ve sosyal mekân özellikleri açısından ayrintılı incelenmiş, tespitler çerçevesinde merdivenli sokakların bulundukları çevreye ve yaşam tarzına katklları değerlendirilmiştir.

Merdivenli sokakların sosyal mekân olarak var olmaları ve kent yaşamina katılmaları sosyal medyadaki görünürlüğü üzerinden, fotoğraf ve video paylaşım uygulaması "Instagram" üzerinden araştırılmış, merdivenli sokakların sosyal medyada görünürlüğ̈̈ kullanıcıların paylaşımları üzerinden değerlendirilmiştir. Araştırma sonuçları merdivenli sokakların çevresindeki yapıların ve fiziksel özelliklerinin sosyal mekân oluşum potansiyeline büyük oranda katkı sağladığını göstermektedir.

Anahtar Kelimeler: mekân algısı, görsel algı, yeniden işlevlendirme, endüstri yapısı

\footnotetext{
${ }^{1}$ Dr. Öğr. Üyesi, İstanbul Gelişim Üniversitesi, E-mail: ilkeciritci@gmail.com

${ }^{2}$ Doç. Dr. İstanbul Gelişim Üniversitesi, E-mail: glyucel@gmail.com

idealkent @ C Kent Araştırmaları Dergisi (Journal of Urban Studies)

http://idealkentdergisi.com

Geliş Tarihi Received Date: 13.08.2020 Kabul Tarihi Accepted Date: 14.04.2021
} 


\title{
Factors Affecting the Formation of Social Space In the Step Streets and Evaluation For Three Examples From Istanbul
}

\author{
İlke Ciritçi ${ }^{3}$ \\ ORCID: 0000-0002-1492-0727
}

Gül Yücel 4

ORCID: 0000-0003-3722-6479

\begin{abstract}
In this study, the potential of social space formation in the step streets and the affecting factors were discussed. Within the scope of the study, step streets, social space, public space, belonging to the city have been researched and aimed to establish conceptual links by associating them with the city. Just as there are popular step streets over the world, there are also step streets which attract attention in the historical regions of Istanbul. With the qualitative research method, the use of the public space of the staircase streets was examined through the parameters of accessibility, comfort, efficiency and aesthetics, and in this context, the success of use as a social space, the potentials of the stairs were determined by on-site observation and measurement methods. Within the scope of the study, Balat Merdivenli Mektep Street, Beyoğlu Hact Ali Street and Üsküdar Yeni Dünya Street are evaluated in detail in terms of physical and social spatial features. Within the framework of the findings obtained, the contributions of the stairs to the environment and lifestyle were examined.

The existence of the step streets as a social space and their participation in the city life were researched through the visibility of the social media, the photo and video sharing application "Instagram", and the visibility of the streets with the social media were evaluated through the users' shares. The research results show that the streets and the physical properties of the streets with stairs contribute to the potential of social space.
\end{abstract}

Keywords: perception of space, visual perception, re-functioning, industry structure

\footnotetext{
${ }^{3}$ Dr. Öğr. Üyesi, İstanbul Gelişim Üniversitesi E-mail: ilkeciritci@gmail.com

${ }^{4}$ Doç. Dr. Öğr. Üyesi, İstanbul Gelişim Üniversitesi, E-mail: glyucel@gmail.com

idealkent (c) Kent Araştırmaları Dergisi (Journal of Urban Studies)

http://idealkentdergisi.com

Geliş Tarihi Received Date: 13.08.2020 Kabul Tarihi Accepted Date: 14.04.2021
} 


\section{Giriş}

Kentsel mekân, kentliyi planlı ya da plansız bir araya getiren, sosyalleşerek, paylaşımda bulunup etkileştiği, yapılı çevre ile doğal çevre bütünüdür. Kentsel mekânlarda gelişen yaşam biçimleri, paylaşımlar, aktiviteler ve kazanımlar bir anlamda kentsel mekânın kalitesini biçimlendirir. Karşılıklı beslemenin gerçekleştiği bu kentsel mekânlarda aynı zamanda kentsel mekânın kalitesi de o kentte yaşayan insanların kültürel aktivitelerini etkiler. Kentsel yaşam koşullarının şekillendirdiği birey ve toplum ilişkisi ve etkileşimi kentin kimliğini güçlendirdiği gibi kentin kalitesinin niteliğini de belirler. Bir mekân ne kadar katılıma açıksa ve paylaşıma imkân tanırsa, o oranda kullanıcıyı etkileşime geçmeye yönlendirir, tercih edilir ve mekânı kullanılır kılar. Bu noktada kentsel mekânın erişilebilir olması ve yaya aksında olması önemli etkenlerden biridir. Aynı zamanda zengin donatı ve sosyalleşmeye katkı sağlar nitelikte olması da önemlidir.

Yapılarla birlikte ulaşım ağı da kentin önemli bileşenidir. Bulundukları coğrafyanın sosyo-kültürel yapısıyla bağlantılı olarak zaman zaman 'yol' olmanın dışında bambaşka görevler de üstlenebilirler. Kimi sokaklar bazı günler pazara dönüşürken, kimi sokaklar ise festivallere ev sahipliği yapabilirler. Bazı merdivenli sokaklar 'Merdivenli Bayır, Merdivenli Çeşme', Merdiven Sokağı' gibi aldıkları isimlerle de kentin imgesel öğelerinden biri olarak, yer aldıkları mekânı tanımlayan ve tamamlayan öğeler olabilmektedirler (Aksu, 2014).

Kentsel mekânlar, kentlilerin bir araya geldikleri ve bu birlikteliklerin neticesinde ortak bir üretim oluşturdukları, mekâna ait belleğin izlerinin yaşatıldığ1 yerlerdir. Fiziki görünümünün ötesinde imgeler oluşturur ve bu imgelerde geçmişin izlerini de beraberinde taşırlar. Sokaklar kültürün ve toplumsal hafızanın yaşatıldığı mekânlardır (Ciritci, 2019). Çakı (2017), Modernleşme ve küreselleşme etkilerine rağmen yaşanılan yerlere (sokaklar, mahalleler) hala güçlü bir aidiyet duygusunun devam ettiğini gösteren araştırmalar olduğunu belirtmektedir.

Kentsel mekân olarak sokakların işlevsel, görsel ve psikolojik olarak başarılı kullanımlarının sağlanabilmesi, ihtiyaçların doğru belirlenip, çevresel verileri doğru kullanarak ve bölge yaşam tarzına uygun, yaratıcı bir tasarımla mümkün olmaktadır. Yapılan yeni düzenlemelerle sosyal kullanıma açılan meydan/kamusal alan/sokak için beklentilerin doğru tespit edilmesi ve sokakların canlandırılması, sosyal kullanıma katılımı için 
yaya kullanım kapasitesi önemlidir. Aktif katılıma yönlendiren, dinlenirken yapılan aktiviteleri izlenebilmesine olanak veren, pasif katılımcının kullanımı da destekleyen mekânlar kurgulanmalıdır. Merdivenli sokaklar yalnızca yayaların kullanımında olmalarından ötürü yayalaştırmaya gerek kalmadan aktif/pasif katılıma olanak sağlayan aktivitelerle zenginleştirerek sosyal kullanıma daha kolay adapte edilebilecek alanlardır. Kimi zaman sanatsal faaliyetlerle görsel olarak kent içinde adeta bir sanat objesine dönüşen sokak, kimi zamansa kendisini sınırlayan binaların zemin kat kullanımının yeme-içme mekânlarına dönüştürülerek, merdivende uygulanan kentsel peyzaj çalışmaları ile cazibe merkezi kazandırma yoluyla olabilmektedir. Merdivenlerde zaman geçirme, sokak sanatçılarının gösterilerini izleme-katılma, çevresinde yer alan manzarayı izleme-dinlenme ya da yalnızca merdivenin veya kendisinin orada olduğunu belgelemek için öz çekim (selfie) fotoğraf çekme amaciyla ziyaret edilen merdivenler kentin önemli odak noktalarından biri haline gelebilmektedir. Merdivenlerin kullanıcılarının birbirleriyle paylaşımlarda bulunup, etkileştiği ve kültürel birikimlerini sergileyebildikleri sosyal birer mekân olarak kente katılımına, yurtdışından pek çok örnek verilebilir. Bunlardan en bilinenleri İspanyol Merdivenleri (Roma, İtalya) (Wikipedia, Spanish Steps, 2020), Dali Müzesi Merdivenleri - Rocky Merdivenleri (Philedelpia, ABD) (Coco, 2019), Caltagirone Santa Maria Del Monte Merdivenleri (Sicilya, İtalya) (Annaloro, 2013), Montee St. Maurice d'Angers Merdivenleridir (Angers, Fransa) (Jobson, 2013) (Resim 1).

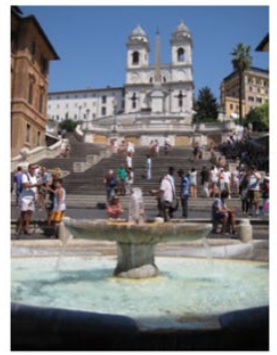

a.

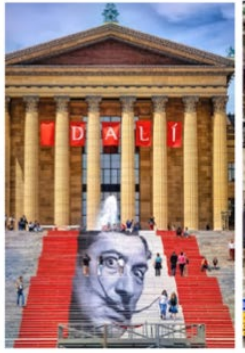

b.

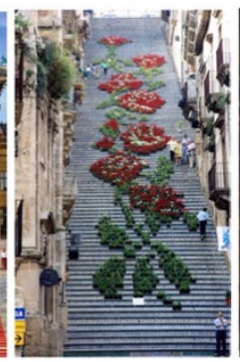

c.

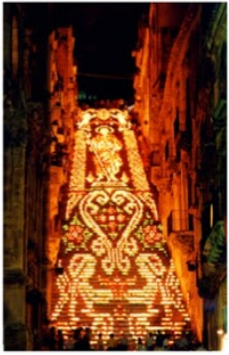

d.

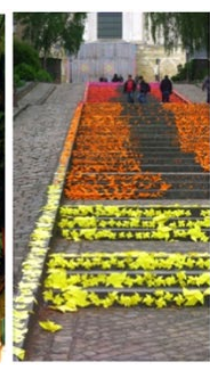

e.

Resim 1. a. Roma-İspanyol merdivenleri, b. Philadelpia-ABD-Dali Müzesi merdivenleri, c. ve d. Sicilya-İtalya-Caltagirone merdivenleri, e. Fransa-Angers merdivenleri

İspanyol Merdivenleri 1723-1726 yılları arasında Roma'da inşa edilmiştir. İsmini, İspanyol toprağı olarak kabul edilen İspanyol Büyükelçi- 
liği'nin Piazza di Spagna (İspanya Meydanı) meydanında bulunması dolayısıyla almıştır. 19.yüzyıl başlarında toplumun farklı kesimlerinden birçok kişi için buluşma noktası haline gelmiştir. Roman Holiday filminde (1953) Audrey Hepburn'un Gregory Peck ile merdivenlerde gezintiye çıkması ile İspanyol Merdivenleri popüler kültürde yerini almıştır (Stabiner, 2016). Çevresindeki yapılar incelendiğinde kâgir tarihi yapıların korunmuş olduğu dikkat çekmektedir. Merdivene komşu yapılardan birinde yaşayan ünlü İngiliz şair John Keats'in zamanında yaşadığı konut, günümüzde müze olarak işlev kazandırılıp varlığını sürdürmektedir. Trinita dei Monti Kilisesi ve meydan arasında yer alan merdivenlerin karşısında ünlü alışveriş caddesi Via Condotti yer almaktadır. Çevre yapılarının merdivene açılan zemin kat kullanımı mevcut değilken, bağlandığı ve yoğun turist sirkülasyonunun bulunduğu meydana açılan tarihi yapıların ticari olarak zemin kat kullanımları bulunmaktadır. Tarihi merkezde yer alan Barok stilde inşa edilmiş olan İspanyol Merdivenleri, 138 traverten taştan oluşmaktadır (Tablo1). Kademelenen basamakları oluşturan doğal taşlar Pincian Tepesinden indirilmiştir (Zusmann, 2020). 17. yüzyıldan beri sanatçılar için ilham kaynağı olmuş merdivenlerde, içinde bulunduğumuz yüzyılda da bazı sanatsal ve politik etkinlikler yapılmıştır. 2008 yılında bir performans sanatçısının merdivenlerden aşağıya 500.000 renkli lastik top bırakması, her bir topun bir politik yalanı temsil ediyor olduğu söylemi ile birlikte, en popüler politik eylem halini almıştır. İspanyol Merdivenlerinde evcil hayvan olarak kedi görülmekle beraber barınma ve beslenmelerine yönelik herhangi kalıcı unsur görülmemektedir. İspanyol Merdivenlerinin sosyal medya görünürlügü ise oldukça yüksektir (Tablo 2).

Amerika Philedelphia Sanat Müzesi'nin girişinde yer alan merdivenler 72 basamaktan oluşmaktadır ve oldukça popüler bir merdivendir. Philadelphia Sanat Müzesi 1876 yılında Fairmount Park'ta kurulan Centennial Sergisi ile kalıcı bir sergi konumuna geçmiştir (Tablo 1). Kutlamalardan sonra Serginin sanat galerisinin Hafıza Salonu adıyla (Memorial Hall) kalıcı olmasına karar verilmiştir. 1920'lerde ise şimdiki ana bina olarak kullanılan binası yapılmıştır (Philadelphia Museum of Art, 2020). Rocky Merdivenleri doğumunun 100. yılı anısına, 2005 yılında düzenlenen Salvador Dali retrospektif sergisi için Dali'nin ikonik imajının merdivenlere yerleştirilmesi ile o dönem Dali merdivenleri olarak da popülerlik kazanmıştır (Philadelphia Museum of Art, 2005). Ancak bunun çok öncesinde merdivenlerin Rocky Steps adıyla meşhur olması Rocky filminde (1979) Slyves- 
ter Stone'un antrenman sırasında basamakları koşar adımlarla çıkma sahnesine dayanmaktadır. Rocky III (1982) filmi sonrasında da Rocky'nin bir heykeli merdivenlere eklenmiştir (Wikipedia, Rocky Steps, 2020). Çevresi müze yapıları ile çevrili olan merdivenin önünde araç yolu ve arkasında meydan bulunmaktadır. Merkezi konumdaki Rocky Merdivenleri'nden şehir manzarasının yanı sıra, Eakins Oval ve Benjamin Franklin Parkway de görülmektedir (Wikipedia, Rocky Steps, 2020). Instagramda 06.06.2020 tarihinde ingilizce \#rockysteps olarak 95bin-96bin arasında, \#rockysteps yanında farklı görsel ekler kullanımı ile birlikte yaklaşı 1000-2000 arasinda \# rockystepshilly olarak 1000-2000 arasında paylaşım yapıldığı tespit edilmiştir, ancak Dali steps olarak hiçbir paylaşım bulunamamıştır. İnternette popüler sitelerde oldukça fazla paylaşılmış olan Dali görseli giydirilmiş merdiven görseli için paylaşımlar, daha çok bilindiği adı ile Rocky Merdiveni olarak yapıldığı görülmüştür (Tablo 2$)^{5}$.

Tablo 1: Dünya' da yer alan bazı ünlü merdivenlerin fiziksel özellikleri

\begin{tabular}{|c|c|c|c|c|c|c|}
\hline Merdivenin adı & $\begin{array}{l}\text { Bulunduğu } \\
\text { ülke/şehir ve } \\
\text { yapıldığı } \\
\text { yıl/yüzyıl }\end{array}$ & $\begin{array}{l}\text { Çevresin- } \\
\text { deki bina } \\
\text { özellikleri }\end{array}$ & $\begin{array}{l}\text { Şehir } \\
\text { içinde } \\
\text { merkezi } \\
\text { konumda } \\
\text { olması }\end{array}$ & $\begin{array}{l}\text { Basamak } \\
\text { adedi ve } \\
\text { malzeme }\end{array}$ & $\begin{array}{l}\text { Manzara(A) } \\
\text { Peyzaj (B) } \\
\text { Tarihi yapı(C) } \\
\text { Meydan } \\
\text { varlığı (D) }\end{array}$ & $\begin{array}{l}\text { Form } \\
\text { Stil }\end{array}$ \\
\hline $\begin{array}{l}\text { İspanyol Mer- } \\
\text { divenleri }\end{array}$ & $\begin{array}{l}\text { İtalya / Roma } \\
\text { 17.yy } \\
(1723-1726)\end{array}$ & $\begin{array}{l}\text { Kârgir, tarihi } \\
\text { binalar }\end{array}$ & Evet & $\begin{array}{l}\text { 138/ doğal } \\
\text { taş }\end{array}$ & A, B, C, D & $\begin{array}{l}\text { Barok stil - doğ- } \\
\text { rusal ve sarmal } \\
\text { dairesel formlu }\end{array}$ \\
\hline $\begin{array}{l}\text { Sanat Müzesi } \\
\text { Merdivenleri } \\
\text { /Rocky merdi- } \\
\text { venleri }\end{array}$ & $\begin{array}{l}\text { ABD / Phile- } \\
\text { delphia } 1876\end{array}$ & $\begin{array}{l}\text { kargir, tarihi } \\
\text { müze binası }\end{array}$ & Evet & $\begin{array}{l}\text { 72/ doğal } \\
\text { taş }\end{array}$ & $\mathrm{A}, \mathrm{B}, \mathrm{C}, \mathrm{D}$ & $\begin{array}{l}\text { Doğrusal form- } \\
\text { dadır. }\end{array}$ \\
\hline $\begin{array}{l}\text { Caltagirone } \\
\text { Merdivenleri / } \\
\text { Santa Maria Del } \\
\text { Monte Merdi- } \\
\text { venleri }\end{array}$ & $\begin{array}{l}\text { İtalya / Sicilya } \\
1604\end{array}$ & $\begin{array}{l}\text { 2-3 katlı ta- } \\
\text { rihi kârgir } \\
\text { binalar }\end{array}$ & Evet & $\begin{array}{l}\text { 142/ doğal } \\
\text { taş ve se- } \\
\text { ramik }\end{array}$ & A, C, D & $\begin{array}{l}\text { Doğrusal form- } \\
\text { dadır. }\end{array}$ \\
\hline $\begin{array}{l}\text { Montee St. Ma- } \\
\text { urice Merdi- } \\
\text { venleri }\end{array}$ & $\begin{array}{l}\text { Fransa /Angers } \\
\text { 12.ve 13. yy'da } \\
\text { Katedral inşa } \\
\text { edilmiştir. }\end{array}$ & $\begin{array}{l}\text { 20.yy yapı } \\
\text { örnekleri, } \\
\text { tarihi binalar } \\
\text { ve peyzaj } \\
\text { düzenleme- } \\
\text { leri }\end{array}$ & Evet & $\begin{array}{l}\text { 100/doğal } \\
\text { taş }\end{array}$ & $\mathrm{A}, \mathrm{B}, \mathrm{D}$ & $\begin{array}{l}\text { Doğrusal form- } \\
\text { dadır. }\end{array}$ \\
\hline
\end{tabular}

5 Popüler sosyal medya platformlarından Instagramda 06.06.2020 tarihinde ingilizce dilinde yapılan arama sonucunda 1milyondan fazla etiketleme görmek mümkündür. '\#spanishstairs, \#spanishsteps, \#spanishstairsrome, \#spanishstepsrome' gibi çok çeşitli adlarla etiketlenmeler yapılması, aynı zamanda kullanıcıların ana dillerinde de yapmış oldukları paylaşımlar eklendiğinde, bu sayının çok üzerinde veri girişi olduğunu ve bu nedenle popüler merdivenlerden biri olduğunu söylemek mümkündür. 
Tablo 2. Dünya'da yer alan bazı ünlü merdivenlerin sosyal özellikleri

\begin{tabular}{|c|c|c|c|c|}
\hline $\begin{array}{l}\text { Merdivenin } \\
\text { adı }\end{array}$ & Sosyal medya görünürlüğü & Sanat etkinliği & $\begin{array}{l}\text { Graffiti ve Evcil } \\
\text { hayvan varlı̆ğ }\end{array}$ & $\begin{array}{l}\text { Popüler olduğu } \\
\text { yıl / olay }\end{array}$ \\
\hline $\begin{array}{l}\text { İspanyol } \\
\text { Merdivenleri }\end{array}$ & $\begin{array}{l}\text { 1milyondan fazla etiketleme } \\
(06.06 .2020) \text { \#spanishstairs } \\
\text { \#spanishsteps \#spa- } \\
\text { nishstairsrome \#spa- } \\
\text { nishstepsrome }\end{array}$ & $\begin{array}{l}\text { Her dönem çeşitli } \\
\text { sanat ve politik } \\
\text { eylemlerde kulla- } \\
\text { nılmıştır. }\end{array}$ & $\begin{array}{l}\text { Kediler bulun- } \\
\text { makla beraber bes- } \\
\text { lenme ve barınma } \\
\text { olanağı bulunmu- } \\
\text { yor }\end{array}$ & $\begin{array}{l}\text { Roman Holiday } \\
\text { filmi (1953) }\end{array}$ \\
\hline $\begin{array}{l}\text { Sanat Mü- } \\
\text { zesi Merdi- } \\
\text { venleri } \\
\text { /Rocky mer- } \\
\text { divenleri }\end{array}$ & $\begin{array}{l}\text { 95bin-96bin \#rockysteps } \\
(06.06 .2020) \text { \#rockysteps, 1000- } \\
2000 \text { arasında \#rockystepshilly } \\
\text {... ancak dali steps olarak hiç- } \\
\text { bir paylaşım bulunamamıştır. }\end{array}$ & $\begin{array}{l}\text { Her dönem çeşitli } \\
\text { sanatsal ve politik } \\
\text { etkinliklerde kul- } \\
\text { lanılmıştır. }\end{array}$ & - & $\begin{array}{l}\text { Rocky filmi 1979- } \\
\text { basamaklardaki } \\
\text { koşma sahnesi, } \\
2005 \text { - Salvador } \\
\text { Dali retrospektif } \\
\text { sergisi }\end{array}$ \\
\hline $\begin{array}{l}\text { Caltagirone } \\
\text { Merdivenleri } \\
\text { / Santa Ma- } \\
\text { ria Del } \\
\text { Monte Mer- } \\
\text { divenleri }\end{array}$ & $\begin{array}{l}1000 \text { in üzerinde (09.06.2020) } \\
\text { \#santamariadelmonte payla- } \\
\text { şımı bulunmaktadır }\end{array}$ & $\begin{array}{l}\text { çeşitli zaman- } \\
\text { larda sanat etkin- } \\
\text { likleri düzenlen- } \\
\text { mektedir }\end{array}$ & $\begin{array}{l}\text { Kediler bulun- } \\
\text { makla beraber bes- } \\
\text { lenme ve barınma } \\
\text { olanağı bulunmu- } \\
\text { yor }\end{array}$ & $\begin{array}{l}\text { 1950'lerin ortala- } \\
\text { rında yerel zanaat- } \\
\text { karlar tarafından } \\
\text { yerel seramikler ile } \\
\text { kaplanması }\end{array}$ \\
\hline $\begin{array}{l}\text { Montee St. } \\
\text { Maurice } \\
\text { Merdivenleri }\end{array}$ & $\begin{array}{l}\text { \#saintmaurice } 10700 \text { gönderi } \\
\text { \#saintmauriceangers 100den } \\
\text { az }(09.06 .2020) \text { \#artaqfest } \\
100 \mathrm{den} \text { az, \#mademoisemau- } \\
\text { rice } 100 \mathrm{den} \text { az... }\end{array}$ & $\begin{array}{l}\text { Çeşitli sanat et- } \\
\text { kinlikleri yapıl- } \\
\text { maktadır }\end{array}$ & $\begin{array}{l}\text { Sadece origami ile } \\
\text { yaratılan graffiti et- } \\
\text { kisi bulunuyor }\end{array}$ & $\begin{array}{l}\text { Angers Festivali } \\
2013 \text { Artaq }\end{array}$ \\
\hline
\end{tabular}

İtalya'nın önemli adalarından Sicilya'da bulunan Caltagirone Santa Maria Del Monte Merdivenleri 142 basamaktan oluşmakta ve tarihi merkezde yer almaktadır (Tablo 1). 1604 yılında inşa edilmiş olan merdivenler 1950'lerin ortalarında bölgedeki zanaatkarlar tarafından yine bölgede üretilen seramikler ile kaplanmış ve bu çalışmadan sonra merdivenler popülarite kazanmıştır. Merdivenlerin bölgede üretilen seramiklerle kaplanması çalışması, 10. yüzyıldan 20. yüzyıla kadar geçerli geleneksel sanat akımlarının kronolojik sırasıyla uygulaması olması neticesinde, Sicilyalı ünlü yazar Leonardo Sciascia tarafından merdivenlere 'Repertuar Merdivenleri' ismi verilmiştir (Italianways, 2020). Şehir manzarası merdivenlere ayrıcalık katarken, sınırlayıcıları olan tarihi yapıların iyi korunmuş olması da merdivenleri cazibe merkezi haline getirmiştir. Aynı zamanda tarihi merkezde bulunan merdivenli sokak yerel zanaat olan seramikçiliğin de yaşatıldığı bir yerdir. Çevre binalarında seramik atölyelerinin ve satış birimlerinin bulunması aynı zamanda otel olarak kullanılan tarihi binaların varlığı, merdivenleri günün her saati kullanılır hale getirmiş ve bazı sanatsal etkinlikler için de merkez haline getirmiştir. Graffitinin bulunmadığı Merdivenli sokakta evcil hayvan olarak kedi görülmekle birlikte barınma ve beslenmelerine yönelik herhangi bir unsur yer almamaktadır. 
Instagram'da İngilizce anahtar sözcüklerle 09.06.2020 tarihinde yapılan aramalarla 1000'in üzerinde \#santamariadelmonte etiketli paylaşım bulunmaktadır. Çoğunlukla basamaklarda çekilen öz çekimler ve basamakların seramik ayrıntılarının merdivenli sokağının geniş açılı perspektif fotoğraflarının paylaşıldığı etiketlemelerde, merdivenli sokağın en yüksek noktasından şehir manzarası fotoğrafları da dikkat çekmektedir (Tablo 2).

Bir başka meşhur merdivenli sokak Fransa Angers'te bulunan Montee St.Maurice Merdivenleri'dir. 1032' de orijinal binası yandıktan sonra 12. ve 13.yüzyılda Angers Katedrali bir diğer adıyla Saint Maurice d'Angers Kathedreli inşa edildikten sonra merdivenler bu adla anılmaya başlanmıştır (Tablo 1). Doğrusal düzende ve 100 basamaktan oluşan merdivenler, Montee Saint Maurice Katedrali ile kıyı boyunca uzanan park alanını birbirine bağlamaktadır. Çevresinde 20.yüzyıl yapıları, tarihi yapılar ve peyzaj düzenlemeleri bir arada yer almaktadır. Sınırlayıcıları olan yapıların çoğu konut olarak kullanılmakta ve zemin kat kullanımları bulunmamaktadır. Tarihi merkezde yer alan merdivenler, Fransız sanatçı Mademoiselle Maurice'in 2013 yılında gerçekleşen Angers Festivali ARTAQ için 30.000 'Origami' çalışmasının öğrencilerin ve çevrede yaşayanların da yardımlarıyla merdiven basamaklarını kaplaması ile popülerlik kazanmıştır (Jobson, 2013). 2013 ARTAQ etkinliği ile görünürlüğü artan merdivenlerin daha sonraki süreçte basamak rihtlarının çeşitli renk ve desenlerle boyanarak farklı etkinliklerde kullanıldığı görülmüştür. Instagram'da 09.06.2020 tarihinde \#saintmauriceangers 100'den az, \#saintmaurice 10.700 'den fazla paylaşımla yer almaktadır. Aynı zamanda \#artaqfest 100 'den az, \#mademoisemaurice 100 'den az sayıda paylaşılmış ve benzer çeşitli isimlerle de paylaşımlar yapıldığı tespit edilmiştir (Tablo 2).

Dünya'da da pek çok örnekte görülebileceği gibi merdivenlerin ilgi çekiciliğini arttırmak için çeşitli resim, çiçeklerle motif yaratma ya da renkli kağıtlarla origami sanatının örnekleri kullanılabilmektedir (Resim 1). Portekiz Lizbon şehrinin Alfama bölgesi de dar ve dik yokuşları ile meşhur bir bölgedir. Lizbon'a kimliğini veren sokakların büyük bir kısmı kentin topoğrafik özelliklerine bağlı, merdivenli sokak olarak gelişmiş ve tarihi yapıların arasında kıvrımlı yapıları ile ziyaretçilerin yoğun olarak ilgisini çekmektedir. Alfama bölgesindeki merdivenli sokaklarda riht ve basamakların renklendirildiği, diğer Dünya örneklerinden farklı olarak, çevreleyen duvarlarında da graffiti - duvar resimleri görülmektedir (Resim 2). 

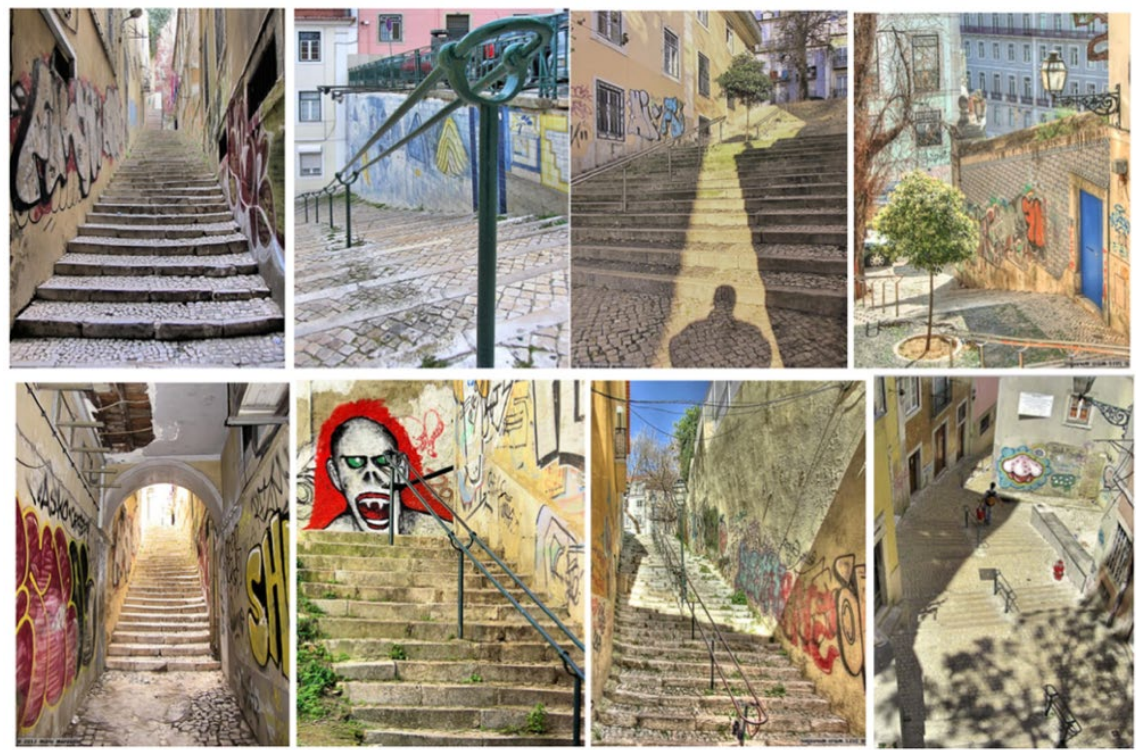

Resim 2. Portekiz- Lizbon, Alfama Bölgesi Merdiven duvar graffiti örnekleri (Marzagao, 2020)

İstanbul'da Kamondo Merdivenleri (Galata), Salı Pazarı Sokağı (Fındıkl1), Enli Sokağı (Beyoğlu)gibi örnekler de sosyal katılıma teşvik eden, kentliyi kent ile etkileşime sokan örnekler olarak gösterilebilir (Resim 3). 2020 yılının yaz aylarının sonlarında Kılıç Ali Paşa Mahallesi'ndeki Enli Yokuşu merdivenlerine Mimar Sinan Üniversitesi öğrencileri ve eski mezunları, Osman Hamdi Bey'in 'Mimozalı Kadın' eserini resmetmiştir. Beyoğlu Belediye Başkanı sanatı sosyal mekânlara, merdivenli sokaklara taşımada kamunun da desteğini verdiğini belirterek, başka örnek uygulamalar için çalışmalar yürüttüklerini belirtmiştir (Murat, 2020).
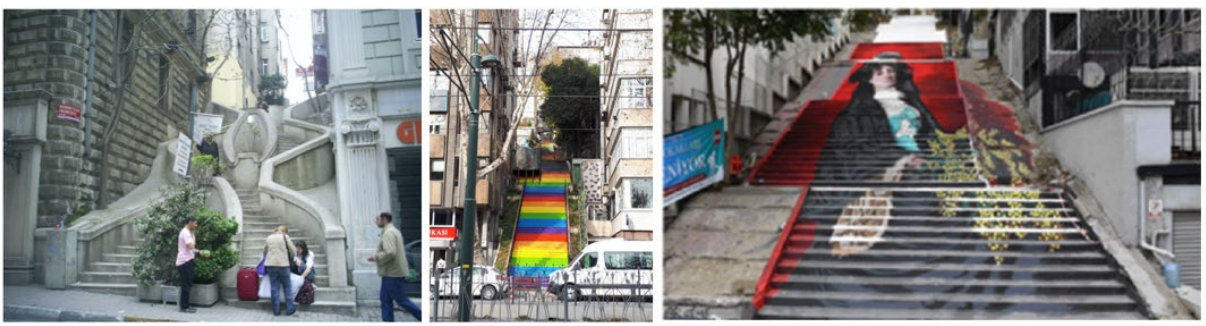

Resim 3. Sırasıyla(1,2,3); Kamondo merdivenleri (Gül Yücel Arşivi, 2019), Salı Pazarı Sokağ 1 (Gül Yücel Arşivi, 2019), Enli Sokağ1 (Murat, 2020) 
Balat semtinde bulunan merdivenli sokak (Merdivenli Mektep Sokak) rıhtları ve basamakları renkli boyanarak bir öz çekim merkezine dönüştürülmüş aynı zamanda da ara kotlarda sahanlıklarla buluşan kafeleri ile merdivenli sokağın kendisi bir cazibe merkezi haline gelmiştir, Karaköy'ü Galata'ya bağlayan güzergahta bulunan Kamondo Merdivenleri (18701880) biçimi ile ziyaretçilerin yoğun ilgisini çekmektedir. Fındıklı'da bulunan Salı Pazarı Sokağı Fındıklı ile Cihangir semtlerini bağlayan güzergâh üzerinde yoğun olarak gençler tarafından tercih edilen merdivenli bir sokaktır. Basamaklarının çeşitli renklere boyanması ile gündeme gelmiş (2013), günümüzde de fotoğraf çekmek isteyenlerin uğrak yerlerinden biridir.

Merdivenler sanat temsil alanı olarak da kullanılmıştır. 9.İstanbul Bienalinde (16 Eylül- 30 Ekim 2005) İstanbul konulu, Charles Esche ve Vasıf Kortun küratörlüğünde düzenlenen sergilerden sanatçı Karl-Heinz Klopf, Beyoğlu'ndan Haliç'e inen merdivenlere dikkat çekmiş, sahne spotları ile aydınlatarak sahne dekoruna dönüştürmüştür.

\section{Literatür Araştırması}

Bir kentin kamusal alanları-kentsel mekânları ne kadar renkli, farklı kullanıc kitlesine hitap edebilir düzeyde ve hareketli ise o kentlinin kent ile kurduğu ilişki, bağ ve kente aidiyeti o kadar kuvvetlidir. Tatlıdil'e göre (2009) kentler sadece bireylerin zorunlu zaman dilimlerini düzenlemekle kalmaz, aynı zamanda o kentte yaşayan bireylerin boş zaman değerlendirme eğilimlerini de şekillendirir ve düzenleyici rol oynar. İnceoğlu ve Aytuğ (2009)'a göre; kentsel mekanlar o kentte yaşayanların kültürel birikimlerini paylaştı̆̆ yerlerdir ve kullanıcıların birbirleri ile etkileşimi sonucu kentli olma deneyimlerini elde etmeleri kentsel mekanlarda olmaktadır. Bu aidiyet kentliyi, yaşadığı kent hakkında düşünmeye, üretmeye ve alınacak kararlar noktasında katılımcı olmaya teşvik eder. Kişiler yaşadıkları kenti benimsedikleri ve aidiyet duygularını geliştirdikleri düzeyde kentten beslenip, kenti beslemeye başlar. Ergen'e göre (2011), Anadolu kültüründe sokaklar iki şekilde biçimlenir; ilki konutların dış duvarları sınırlandırmaları ile oluşan sokak tipleri, bir diğeri ise yapıların sokakla bahçe kullanımı yaratacak şekilde birleşmesi şeklinde oluşan sokak tipleridir. 
İstanbul'da, sokakların araç yoğunluğu nedeni ile yaya kullanımını tehdit etmesine dikkat çekmek üzere kurulmuş olan 'Sokak Bizim Derneği' her ayın belirli bir günü bir sokağı araç kullanımına kapatarak yayalar ve bu deneyimi yaşamak isteyen kentliler için etkinlik düzenlemiştir. 2007 yılında düzenlenen 'Towards World Carfree Cities' konferansı çerçevesinde pilot proje olarak ilk defa gerçekleştirilen etkinlik, Şişli'de dört farklı sokağı trafiğe kapatarak uygulanmış ve başarılı tepkiler aldıktan sonra etkinliklerin ayda bir farklı sokakların seçilerek yapılmasına devamı kararı alınarak dernek kurulmuştur. 2010 yılında son etkinliğini yaparak faaliyetlerine son verilen derneğe benzer, belediyelerin ve bazı özel kurumların desteği ile 'Sokağını yaşa', 'Aklımdaki Mahallem' gibi farklı girişimler de olmuştur. Tüm girişimlerde hedeflenen ortak amaç sokakların sosyal mekân olarak değerlendirilebilmesi ve bu etkinlikler aracılığıyla ile kentin sosyal yaşamına katkı sunmaktır (Ekoyapı, 2013) (Sokakbizim, 2020). Söz konusu etkinliklerle yer aldıkları toplumun kolektif hafızasında da yerlerini almışlardır. Özbayraktar'a göre (2015) sokaklar geleneksel fiziksel tanımının ötesinde kolektif belleğe katkıları ya da sembolik anlamları gibi farklı özellikleri betimlenerek de tanımlanabilmektedir (Özbayraktar, 2015). En ilgi çekici tariflerinden biri de sokakların kamusal alan olarak sosyalleşme sürecini sağlamasının bu alana girme serbestliği üzerinden tanımlanma biçimidir. Bir diğer önemli tarif ise sokaklar aracığıyla aynı zamanda kentlinin fizyolojik, güvenlik ve en önemli ihtiyaçlarından biri olan aidiyet ihtiyacının da karşılanması tarifidir. Özbayraktar (2005)'ın 'sokak' kelimesine geniş bir perspektiften bakılmasını sağladığı tanımlarını; sokakların, fiziksel birer kent mekânı olma özelliğinden ve s1nırları üzerinden gelişen tanımların çok ötesinde, kentlinin duygularını, kendi (sokak) üzerinden kentle ilişkisini şekillendiren bir öğe olduğu şeklinde okumak da mümkündür. Diğer taraftan merdivenli sokaklar özelinde afet riskleri ve ulaşılabilirlik konuları güvenli kullanım açısından öne çıkmaktadır. Gerekebilecek acil tahliye durumunda uygun koşulların sağlanması güvenli kaçış için yaşamsal bir önem taşımaktadır (Yücel, Ciritci, 2000).

White (2000), kamusal alanı başarılı kılan dört temel özelliği; ulaşılabilir olmaları, insanların çeşitli aktivitelerde bulunmaları, mekânın konforu ve iyi bir imajın olması ve sosyal faaliyetleri destekleyen, samimi, insanların buluşarak sosyal etkileşimin sağlanabildiği mekânlar olarak tanımlamıştır (White, 2000). Uzgören ve Erdönmez kamusal açık alanlarda mekân kalitesini araştırdıkları çalışmada bir alanın mekânsal kalitesinin 
burada gerçekleşen aktivitelerin çeşitliliği, süresi ve aktiviteyi gerçekleştiren kullanıcıların sosyo-ekonomik yapıları ile doğrudan ilişkili olduğunu tespit etmişlerdir (Uzgören, Erdönmez, 2017). Bu çerçeveden bakıldığında bir sokağın da mekânsal kalitesinin ölçümünde benzer parametreleri kullanmak ve bulgular çerçevesinde sokağın mekânsal kalitesinin ölçülmesi mümkündür. İnceoğlu ve Aytuğ (2005)'un, Ven der Voort, Van Wegen, Greene, Lynch, Nasar, Brunswick, Gehl, PPS gibi pek çok araştırmacının mekânsal kalitenin ölçmesi ve değerlendirmesi konusunda belirledikleri parametreleri inceledikleri çalışmaya göre, kentsel mekânın kalitesinin değerlendirilmesinde ortak bazı parametreler bulunmaktadır. Bu parametreler; imaj ve kimlik, cazibe ve gidilecek yer, esnek tasarım, konfor, mevsimlik strateji, mekânın girişi, sınırlayıcıları (iç ve dış sınırları) ve mekânın ulaşılabilirliğidir.

\section{Yöntem}

Araştırmada İstanbul için sosyal mekân olma potansiyeli taşıyan merdivenli sokakların kendine özgü yapısının ortaya çıkarılması hedeflenmiştir. Çalışma kapsamında sokak, merdivenli sokak, sosyal mekân, kamusal alan, aidiyet kavramları mimarlık literatüründe araştırılmış, kentle ilişkilendirilerek, kavramsal bağlar kurulması amaçlanmıştır. Bu bağlamda İstanbul'un tarihi bölgelerinden Beyoğlu, Fatih ve Üsküdar'da bulunan ve yoğun olarak kullanılan birer merdivenli sokak örneği seçilerek yerinde ayrıntılı incelenmiştir. İstanbul topoğrafya açısından tepeleri ve denizle bağlantılı olarak dik yokuşları olan bir şehirdir. Geçmiş yüzyılların da izlerini taşıyan bu yokuşların bir kısmı günümüzde hala yokuş olarak kalmış bir kısmı ise zamanla yaya kullanımına kolaylık getirmesi açısından merdivenli sokak ya da yokuş ve merdivenin bir arada kullanımın olduğu sokaklar halini almıştır. Tarihi semtlerde yer alan merdivenli sokaklar, kentin tarihi bölgelerinin yoğun kullanımına paralel, günün belirli saatlerinde sosyal anlamda da kentlinin birbiri ile etkileşime geçtiği, kültürünü paylaştığ 1 yerler olarak önem kazanmaktadır. Seçilen merdivenli sokakların, kentin önemli düğüm noktalarında yer alıyor olmaları karşılaştırma açısından önem taşımaktadır. Bu nedenle özellikle merdivenli sokaklar İstanbul'un önde gelen tarihi semtleri olan, Fatih bölgesinden (Merdivenli Mektep Sokak), Beyoğlu bölgesinden (Hacl Ali Sokak) ve Üsküdar bölgesinden (Yeni Dünya Sokak) seçilmiştir (Resim 4). Hacı Ali Sokağı, Yeni Dünya Sokağı ve Merdivenli Mektep Sokağı İstanbul'un eski yerleşim 
yerlerinden ve tarihi oldukça gerilere dayanan semtleri olan Fatih, Beyoğlu ve Üsküdar'da yer almaktadır (Resim 4).

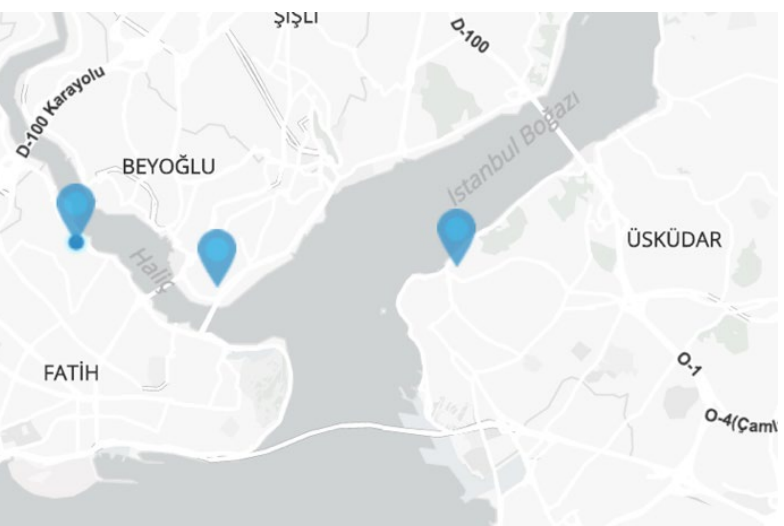

Resim 4: İstanbul haritası üzerinde seçilen merdivenlerin konumu (Şehir Haritası, 2020)

Nitel araştırma yöntemi kullanılan çalışmada literatür araştırması, saha gözlemi, belgeleme ve ölçüm yöntemleri ile veri toplanmıştır. Elde edilen bulgular çerçevesinde merdivenli sokakların bulundukları çevreye ve yaşam tarzına katkıları incelenmiştir. Sahadan toplanan veriler üzerinden, fiziksel özellikleri, güçlü ve zayıf yanları, merdivenli sokakların sosyal mekân olarak kullanılma tercihleri ve kullanım eğilimleri araştırılmıştir.

Dijital teknoloji taşınabilir hale geldikçe, insanların kendini ifade etme araçları da değişmektedir. Sosyal ağlarda paylaşılan durum ve yer bildirme, günümüzde öz çekim ve yaygın görsel konuşmaya dönüşmüş yeni bir kültürü oluşturmaktadır. Günümüzde popülarite, sosyal medya paylaşım sitelerinde popülerliği araştırılan nesne ya da mekânın adının ne kadar sıklıkla kullanıldığı üzerinden ya da etiketlenip paylaşılan fotoğraflar üzerinden de ölçülebilmektedir (Uzundumlu, 2015). Kesin bir veri olmamakla birlikte, merdivenli sokakların sosyal kullanım açısından değerlendirilmesinde sosyal medyada paylaşım düzeyi ön bilgi olarak kullanılabilir. Bu kapsamda çalışmada merdivenli sokakların da sosyal mekân olarak var olmaları ve kent yaşamına katılmaları, sosyal medyada görünürlüğüne ilişkin kullanıcı paylaşımları üzerinden de değerlendirilmiştir. Çalışmada ayrıntılı incelenen merdivenli sokakların sosyal medyadaki görünürlüğü, fotoğraf ve video paylaşım uygulaması "Instagram" üzerinden araştırılmıştır. Sosyal medya görünürlüğüne ilişkin veriler, her bir sokak 
için 2020 yılı ilk çeyreğinde yapılan tarama sonuçlarına göre dikkate alınmıştır. Çalışmada yoğun kullanılan ve konumlandıkları düğüm noktalarında insanların etkileşime geçebildiği, insanların sosyal paylaşımlarına potansiyel yaratmaları sayesinde ek işlevler kazanan merdivenli sokaklar olması dolayısıyla seçilen üç farklı konumdaki merdivenli sokaklar, White'ın (2000), kamusal alanı başarılı kılan dört temel özellik olarak belirlediği parametrelerden ulaşılabilirlik, etkinlik, konforu ve imaj-estetik açısından incelenmiştir. Ulaşılabilirlik parametresi merdivenli sokağın lokasyon açısından konumlandığı yerin tespiti, merkezi olma durumu; konfor parametresi merdivenli sokakların fiziksel ve çevresel özelliklerinin ölçülmesi, etkinlik parametresi merdivenli sokakta yapılan etkinliklerle sosyal medyada kazandığı görünürlügün değerlendirilmesi ve estetik parametresi ise fiziksel özelliklerinin bütününün değerlendirilmesi başlıklarıyla incelenmiştir. Basamak sayısı, rıht ve basamak genişliği ölçüleri, kullanılan malzemenin özelliği merdivenli sokağa açılan yapıların kullanım özellikleri, peyzaj ya da tarihi yapı varlığı gibi özellikler merdivenli sokağın fiziksel özelliklerini betimlerken, sokağın kullanım sıklığı, kullanım amacl, sokak üzerindeki duraklar ve sosyal medya görünürlüğü ise merdivenli sokakların sosyal özelliklerini betimlemektedir. Evcil hayvan ve graffiti (duvar boyama sanatı) varlığı özellikle Türkiye'de görülen sosyal yaşamın bir uzantısı olarak betimlenebilecek bir olgudur. Çalışma kapsamında yapılan gözlemlere bağlı olarak; duvar boyama sanatının sıklıkla yer bulması ve sokak kedilerini sokakta sahiplenmenin bir uzantısı olarak kediler için besleme ve barınmaya yönelik müdahaleler, bir açıdan merdivenli sokaklardaki ortak sosyal mekân kullanımına ilişkin bulgular olarak gösterilebilir.

\section{Tespitler}

\section{Beyoğlu Hacı Ali Sokă̆ı}

Hacı Ali Sokak Beyoğlu Bereketzade mahallesinde bulunmaktadır. 19. yüzyılda İstanbul içinde özel bir fiziksel çevre ve yaşam biçimi yansıtan Galata ve Pera, yaklaşık 1914'lere dek canlılığını ve önemini sürdürmüştür. 1990'lara gelindiğinde, Beyoğlu tekrar eski önemini kazanmaya başlamış, daha korumacı ve çözümleyici bir yaklaşımla; 1993 yılında Galata ve Beyoğlu, kentsel sit alanı olarak ilan edilmiştir (Aytar, 2013). Son 20 yılda çeşitli kültürel etkinliklerin ağırlıklı bu bölgede düzenlenmesi, birçok sanat dalından atölye ve sanatçıların bölgeyi tercih etmeleri Karaköy- 
Galata bölgesinde değişimi beraberinde getirmiş, bölgeye ilginin artışında etken olmuştur.

Hacı Ali Sokağı Beyoğlu ilçesinde Bereketzade Mahallesi'nde, Karaköy'den Galata'ya çıkış güzergâhında turistik, tarihi, merkezi konumda, kendisini sınırlayan önemli yapılara da komşu konumdadır. Voyvoda Caddesi'ni 71 basamak ile Felek Sokağı'na bağlamakta, arada Banker Sokak da bulunmaktadır. Başlangıcı ile bitişi arasında yaklaşık 14 metre kot farkı bulunan Hacı Ali Sokağı, sosyal anlamda da özellikle ziyaret edilen, kesişme ve odak noktası durumdadır. Sokağı sınırlayan yapılar arasında bazı önemli yapılar da bulunmaktadır. Felek Sokak ile Hacı Ali Sokağın kesişiminde bulunan ve restorayonu Mimar Cemal Ekingen tarafından gerçekleşen Felek Han'ı (Günümüzde Galata Konutları Apart Otel olarak işlevlendirilmiştir) bunlardan biridir (Tuna, 1999). Karaköy-Galata-Beyoğlu semtleri yıl içerisinde oldukça fazla sanatsal etkinliğe ev sahipliği yapmaktadır. Sanatsal etkinliklerin yanı sıra bu bölgede tasarım ofisi ve etkinlik ve müzik atölyeleri de bulunmaktadır. Hacı Ali Sokağının bu güzergâh üzerinde oluşu adının pek çok sanatsal etkinliklerde anılmasına sebep olmuştur.

Basamakların bitiminde yokuşla devam eden Hacı Ali Sokağı konfor ve ulaşılabilirlik parametreleri altında fiziksel olarak incelendiğinde iki bölümden oluşmakta olduğu görülmektedir (Tablo 3). Geniş basamak yapısı ve görece alçak rıht özelliği taşımaktadır. Her iki yanda bina ile sınırlı merdivenli sokağın genişliği ise derin gölge oluşturacak biçimdedir. Arada sahanlık bulunan merdivenli sokağın sadece ikinci bölümünde korkuluk yer bulmaktadır (Resim 5). Merdivenli sokak basamakları yenilenmiş durumda ve rıhtları farklı renklerde desen oluşturacak şekilde boyanmıştır. (Resim 5).
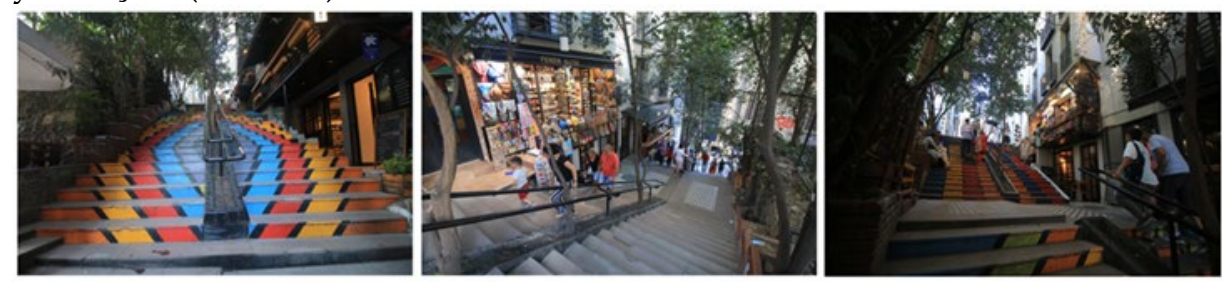

Resim 5. Haci Ali Sokağı genel görünüm, Temmuz 2019 (Gül Yücel Arşivi)

Hacı Ali Sokak'ın çevresinde peyzaj, tarihi bina ve meydan bulunmaktadır. Aynı zamanda merdivene sınır oluşturan yapıların duvarlarında 
duvar resmi bulunmakta ve merdivende evcil hayvan(kedi) beslendiği için kedi evi, mama kabı ve benzeri eklentiler de görülmektedir.

Sokak oldukça yoğun turistik bir güzergâhta bulunmasından dolayı günün her saati yoğun ilgi görmektedir. Bu nedenle turistlerin fotoğraf çekmek için ziyaret etmelerine ilave olarak kafelere ve merdivene açlan ticaret amacıyla kullanılan mağazalara da ziyaret gözlemlenmiştir. Yoğun olarak ticaret, kültür ve eğlence mekânlarının bulunduğu sokağın kullanım amacı incelendiğinde ziyaret, ulaşım ve kamusal alan kullanımı ön plana çıkmaktadır. Merdiven alt kotta Karaköy Meydanı'na açılmaktadır. Buluşma noktası olarak oldukça yoğun kullanılan bir dügü̈m noktası olan ve deniz kıyısına yakın konumda olan meydanda aynı zamanda yeme içme mekânları da bulunmaktadır.

Sosyal medya görünürlügüne yönelik Mayıs 2020 tarihinde "Hacı Ali Sokak" etiketi ile yapılan internet taramasından elde edilen sonuçlara göre 100'ün üzerinde fotoğraf paylaşımı yapıldığı görülmektedir. Bu sayılar belirli bir zaman aralığında değil, arama yapılan tarihe kadar olan tüm aramaları kapsadığından, aramanın 2020 Mayıs ayına kadarki tüm etiketlenmeleri gösterdiği söylenebilir (Araştırma tarihi 2013-Mayıs 2020 denilebilir; başlangıç tarihi; Instagramda yer alan etiketleme özelliğinin geldiği 2013 yılından itibaren tüm etiketlenmeleri göstermektedir.) Paylaşımlarda sıklıkla öz çekimlere yer verildiği, renkli basamakların ve çevresindeki dükkân cephelerinin fon olarak kullanıldığı görülmüştür.

\section{Üsküdar, Yeni Dünya Sokağı}

Üsküdar İstanbul'un tarihi ve doğal güzelliklerinin iyi korunabildiği çok az semtten biridir. Tarihi Bizans Dönemine kadar dayanır. Ancak Osmanlı Dönemi'nde Mimar Sinan yapıları ile semt ayrı bir önem kazanmıştır. Osmanlı Dönemi'nde Üsküdar'da inşa edilen askeri, eğitim, sağlık, dini ve ulaşım alanındaki yapıların çoğu günümüze korunarak gelebilmiştir. Yeni Dünya Sokağı Üsküdar'da oldukça yoğun kullanılan bir aks olan Selmenağa Çeşmesi Sokak ile Yeni Dünya sokak arasında konumlanmaktadır (Resim 6). Kurşunlu Medrese sokağın bağlandığı Yeni Dünya Sokağı'nı bina ve bahçe duvarı sınırlamaktadır. Doğrudal yapıda ve 125 basamağı olan merdivenli sokak üst kota yakın bir kısmında 26 basamakla başka bir doğrultuda ikinci bir kolla bağlanmaktadır. 

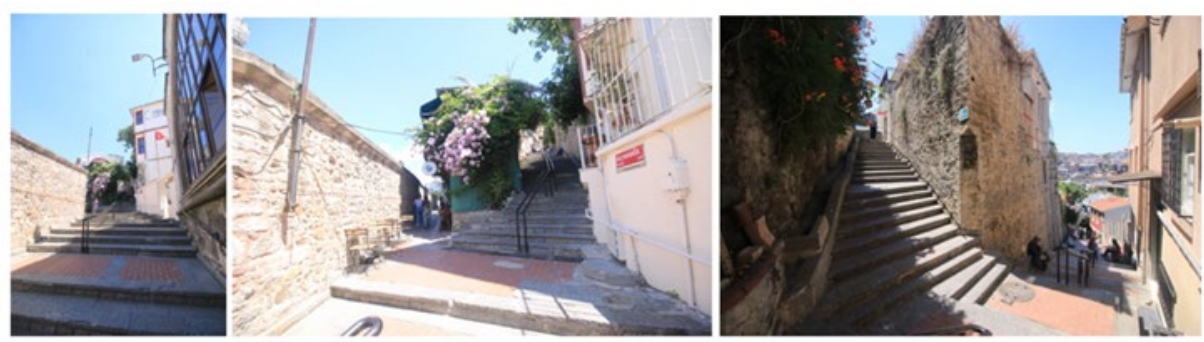

Resim 6. Yeni Dünya Sokağı genel görünüm, Temmuz 2019 (Gül Yücel Arşivi)

Yeni Dünya Sokağı'nda peyzaj, manzara, tarihi bina varlığı ön plana çıkan unsurladır. Başlangıcını Üsküdar meydanının devamı niteliğinde, Mihrimah Sultan Cami yanından çıkan sokağı sınırlayan bina cephelerinden birinde temsili bir konu resmedilmiştir (Resim 9). Evcil Hayvan varlığ da gözlemlenen sokak üzerinde kedi evleri ve mama, su kabı gibi ihtiyaçları için de malzemelerin olduğu tespit edilmiştir. Konut, ticaret, kültür ve eğitim işlevlerine hizmet eden yapıların bulunduğu sokağın kullanımının yoğun olduğu ve konut, ziyaret, ulaşım ve kamusal alanları kullanım amacıyla ziyaret edildiği gözlemlenmektedir. Merdivenin bağladığ sokaklar arasındaki güzergahı boyunca doğal yeşil alanların varlığı, mevsimine göre çiçeklerinin renkleri ve bakımlı durumdaki tarihi yapılarının bir arada fotoğraf çekmek için cazibe noktası durumundadır. Sosyal medya (Instagram) araştırmasına göre Yeni Dünya Sokak etiketiyle gönderilerde bulunduğu görülmektedir. Paylaşılan fotoğraflarda ağırlıkla eski yapılar ve merdiven ilişkisi ile yeşil dokunun merdiven ile ilişkisine yer verildiği görülmüştür.

\section{Fatih, Merdivenli Mektep Sokağı}

Merdivenli Mektep Sokak Fatih ilçesinde Balat semtinde bulunmaktadır. Özellikle 2000 yılından sonra semtte yer alan yapıların üniversite, yüksek okul, tasarım ofisi, reklam ajansı, film setine dönüştürülmesi ile ve bazı sanatçıların bölgede konut alıp yerleşmesi ile sosyo kültürel bir değişim daha yaşanmıştır. Semtin fiziksel olarak iyi korunmuş yapıları ve sokakları kısa zamanda tüm ziyaretçiler için cazibe merkezi haline gelmiştir.

Balat Semti'nde bulunan Merdivenli Mektep Sokak, Tevkii Cafer Mektebi Sokak ile Sancaktar Sokak arasında konumlanmaktadır (Resim 8). Sokak boyunca ağaçlar bulunmaktadır. Korkuluk, merdivenli sokağın yer yer görece geniş kısımlarında bulunmaktadır. Sokağın basamak ve rıhtları tamamen yenilenmiştir (Resim 7). 

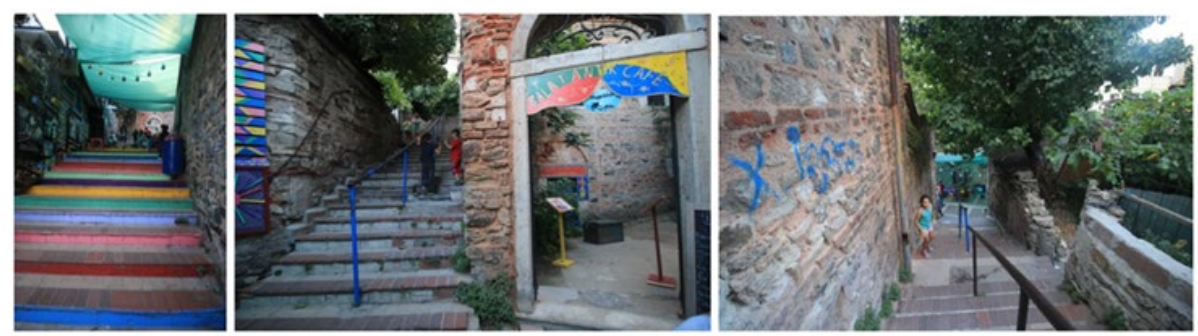

Resim 7. Merdivenli Mektep Sokağı genel görünümü, Temmuz 2019 (Gül Yücel Arşivi)

Sokağın alt kotunda ziyaretçilerin yoğun olarak bulunduğu meydan bulunmaktadır. Sokak üzerinde kültür ve eğlence mekânları bulunmakta, çok yoğun olarak kullanılan merdivenli sokak çoğunlukla ziyaret, ulaşım ve kamusal amaçlı kullanılmaktadır.

Sosyal medyada Merdivenli Mektep Sokak etiketiyle özçekim, doğa, manzara ve duvar resimlerinin benzer oranlarda paylaşıldığ1 görülmüştür. Çalışma kapsamında seçilen üç merdivenli sokak örneğinde de merdiven çevresi tarihi yapı, bahçe duvarı gibi unsurlarla çevrilidir. Hacı Ali Sokağı (Beyoğlu), Yeni Dünya sokağı (Üsküdar), Merdivenli Mektep Sokak (Fatih)'ın üçünün de sınırlarını binalar ve bahçe duvarları oluşturmaktadır. Her üç merdivenli sokağın da üzerinde ağaç ve korkuluk vardır aynı zamanda yenilenmiştir. Basamak malzemeleri incelendiğinde her üç merdivenli sokağın basamaklarında yapay taş kullanılmıştır ancak Yeni Dünya Sokağı'nda diğer iki sokaktan farklı olarak rıhtlarında yapay taş değil, doğal taş kullanılmıştır ve kısmen özgün malzeme varlığından söz edilebilir (Tablo 3). Her üç sokakta da tarihi yapı, peyzaj, meydan, duvar resmi ve evcil hayvan varlığı bulunmaktadır. Her üç merdivenli sokağın da tarihi kent manzarası olması karşın deniz manzarası yalnızca Yeni Dünya Sokağı'nda vardır. 
Tablo 3. Araştırılan merdivenli sokakların Özellikleri

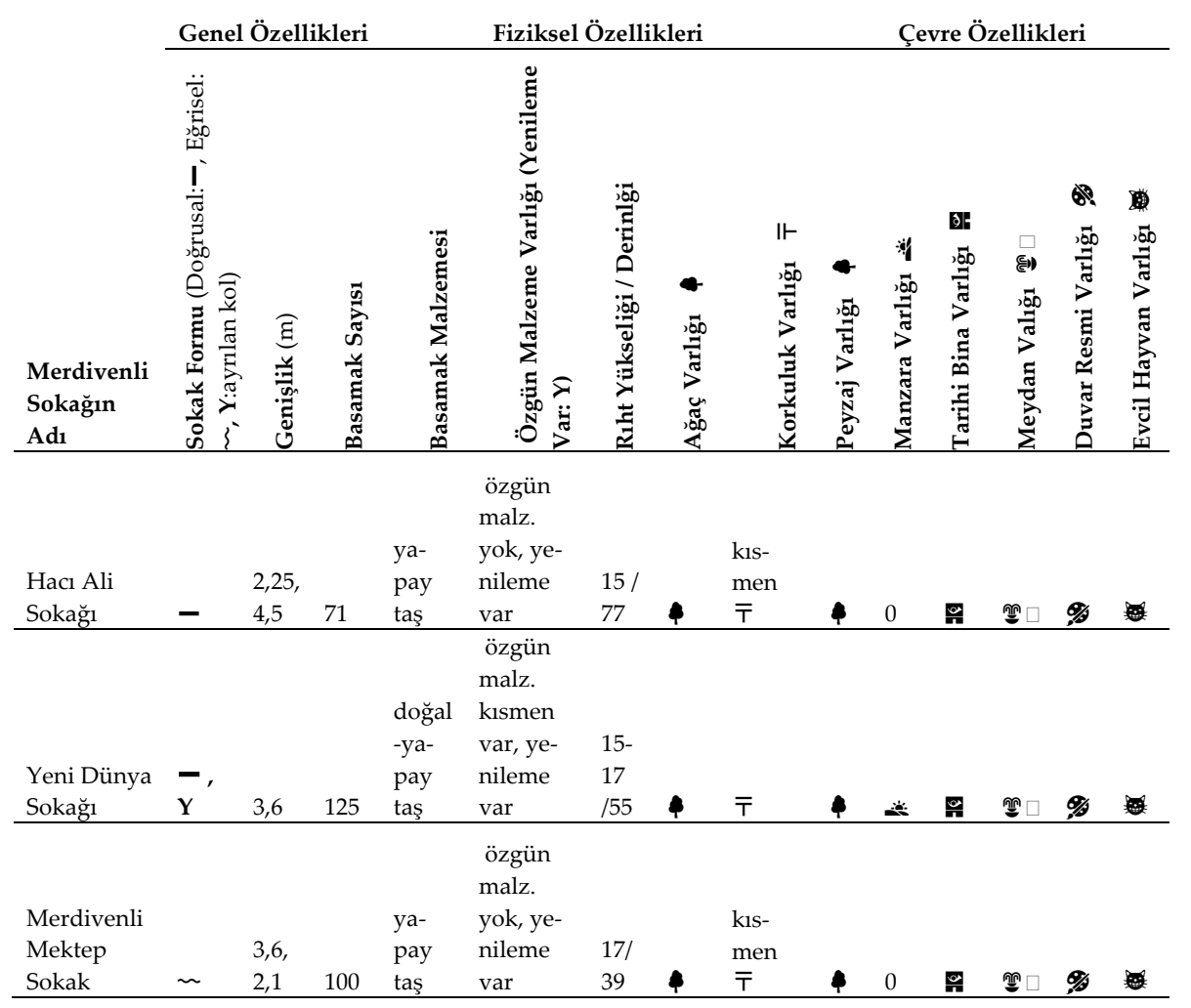

Yeni Dünya Sokağı konutlara, ticari yapılara, eğitim yapılarına ve kültür yapılarına erişim amacı ile de kullanılırken Hacı Ali Sokağı ticari yapılara, kültür ve eğlence yapılarına; Merdivenli Mektep Sokak ise kültür ve eğlence yapılarına erişim için kullanılmaktadır. Yoğunluk olarak ise Hacı Ali Sokağı ve Merdivenli Mektep Sokak çok yoğun kullanılırken, Yeni Dünya Sokağı orta yoğunlukta kullanılmaktadır. Kullanım çeşitliliği ve yoğunluk açısından incelendiğinde bazı çıkarımlara ulaşmak mümkündür. Manzara sadece Yeni Dünya Sokak için belirgin unsurdur. Manzaranın tek başına varlığı eğlence mekânları ile desteklenmediği zaman sokağın sosyal mekân olarak kullanım yoğunluğunu arttırmaya yetmemektedir. Ancak her üç merdivenli sokak da meydandan, kültür yapılarından ve tarihi yapılardan beslenmesi karşın; Hacı Ali Sokak ve Merdivenli Mektep Sokak üzerinde yeme- içme mekânlarının bulunması aynı 
zamanda bu iki merdivenin sosyal mekân olarak kente çok yoğun bir kullanım ile katıldığını göstermektedir. Hacı Ali Sokağı' nın Karaköy ve Galata Kulesi Meydanları arasında bir aks olması bölgenin mevcut potansiyelinden de yararlanabilmesini sağlamaktadır.

\section{Sosyal katılımın Türkiye'ye özgü dışavurumu: Sokak hayvanları, duvar resimleri, öz çekim ile sosyal medyada görünürlük}

White'ın (2000) kamusal alan başarı ölçütlerinde yer bulan 'etkinlik'; çalışma kapsamında merdivenli sokakların kamusal alan olarak sosyal katılımının oranının/potansiyelinin sosyal medya platformları üzerinden ölçülmesi şeklinde incelenmektedir. Sokak boyunca evcil hayvan varlığ açıdan insanların evcil hayvan bakımını aktivite ve etkinlik olarak değerlendirmesi ve sosyal medyada paylaşması yoluyla görünürlük sağlaması da bu kapsamda değerlendirilebilir. Kedilerin merdivenlerin üzerinde bulunmaları yaşamlarının merdivenli sokak üzerinde devam ettirilebilir olduğunu göstermektedir. Ancak incelemelerde yaşamlarını devam ettirmeleri için gerekli olan mama kabı ya da barınmaları için kedi evlerinin merdivenli sokak üzerinde olmamasından, sokak üzerinde yaşayan kedilerin günübirlik ziyaretçilerin ya da sokakta mevcutta yaşayan insanların bir arada bakımlarını üstlenmesinden çok, bireysel bazı işletmelerin kendi fiziksel mekânları içerisinde kedilerin bakımlarını karşılıyor olma ihtimalini kuvvetlendirmektedir. Sokak hayvanlarının bakımı ve özellikle kediler için merdivenli sokakların birçoğunda geçici veya kalıcı düzenlemelere gidilmiştir (Resim 8). Kedi evi olarak farklı boyut, tasarım ve malzemeyle birçok örnek merdiven sahanlıklarında veya aradaki yeşil bantta yer aldığı gözlenmektedir.
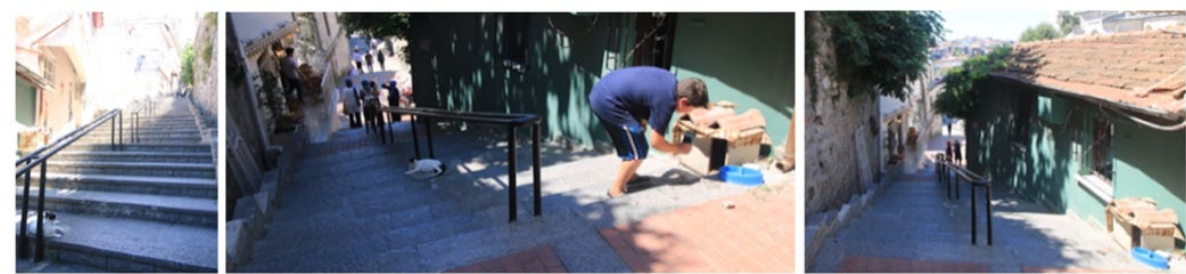

Resim 8. Yeni Dünya Sokağı üzerinde kedi evi, Temmuz, 2019 (Gül Yücel Arşivi)

Duvar resimleri, diğer bir değişle graffiti, kentsel mekânda birçok alanda sokak sanatının önemli bir parçası olarak günlük yaşama dâhil olmaktadır. 
Conklin (2012) sokak sanatı ve kamusal alan ile ilgili araştırmasında kamusal alana erişimin öneminden bahsetmekte ve bu alanların demokratik eylemler için fiziksel arenalar olarak hizmet ediyor olmasından ötürü ekonomik, sosyal ve politik sistemlerin toplumu desteklemediği belirsiz zamanlarda, graffitinin tabandaki fikirleri iletmenin en etkili yolu olduğunu ve toplum içerisinde bir çeşit empati sağladığını söylemektedir. Conklin (2012)'e göre bireyler arasında bağ kurabilen kültürel bir faaliyet olan graffitide anlamlar her zaman açık değildir, orada var olan ile kendi hayal gücümüzü birleştirip izleyiciyi soru sormaya ve yerle etkileşime geçmeye teşvik etmektedir.

Graffiti diye adlandırılan duvar resimlerin varlığı da bir çeşit resim sanatının farklı yollarla kendini var ettiğini, mesaj ve protest bir tavırla duvarlarda insanlara sunulmak üzere merdivenli sokağın sosyal mekân olarak kullanıldığını göstermektedir. Son yıllarda "mural" (renkli duvar resimlerine verilen isim) uygulamalarının uluslararası düzeyde festivallerle İstanbul'da yer bulduğunu söylemek mümkündür. ${ }^{6}$ Duvar resimlerinin, graffitilerin semtlere göre değişik şekillerde yansıtıldığı ve daha çok Beyoğlu semtinde yoğunlaştığı söylenebilir (Resim 9).
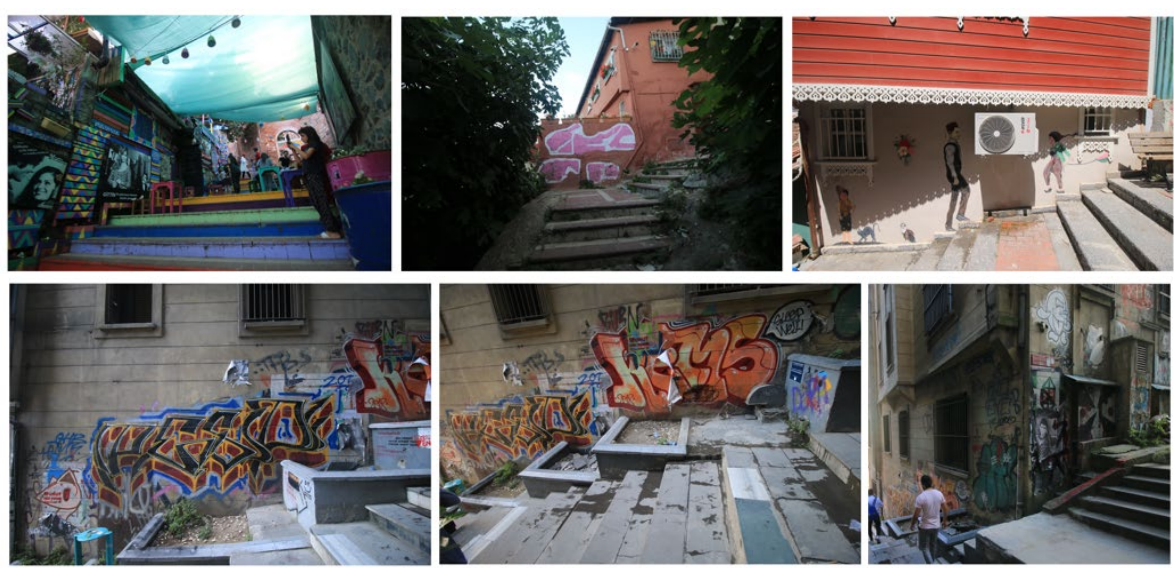

Resim 9. Sirasıyla; (1,2,3)Hacı Ali Sokak, (4,5)Merdivenli Mektep Sokak, (6)Yeni Dünya Sokak, Temmuz 2019 (Gül Yücel Arşivi)

İncelenen merdivenli sokaklarda özellikle öz çekim ve fotoğraf çekimleri sık yapılan bir aktivite olarak gözlemlenmiştir (Resim 10). Bazı zamanlarda

${ }^{6}$ Kadıköy Mural Festivali. 
özel bir sanatsal çalışmanın ya da doğa güzelliklerinin olduğu bölgede fotoğraf çekimleri sırasında merdivenlerde sıkışma, sıra bekleme olduğu görülmüştür.
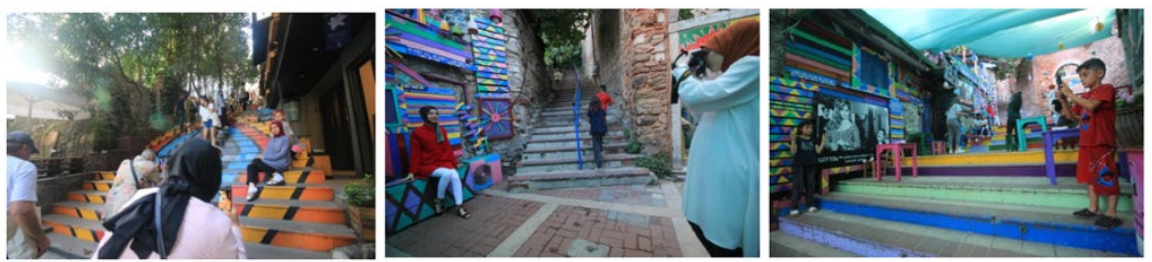

Resim 10. Merdivenlerde Özçekimler (1)Hacı Ali Sokak, $(2,3)$ Merdivenli Mektep Sokak, Temmuz 2019 (Gül Yücel Arşivi)

Bazı yeme-içme mekânlarının sahanlıklara taştığı/açıldığı merdivenlerde, çocukların korkuluk gibi merdiven bileşenleri ile ya da sahanlığın üzerinde oyun oynadıkları görülmektedir. Çocukların merdivenli sokağı oyunlarına katıp, kurallar geliştirip oyunun bir parçası haline getirmesi durumu, tam da o semtin çocuklarının dünyasında merdivenleri sokakların sosyal mekân olarak kullanılmasına bir örnek niteliğindedir (Resim 11). Bu eylemlerin tümü kullanıcıların, kentlinin merdivenle etkileşimine açık bir örnektir.
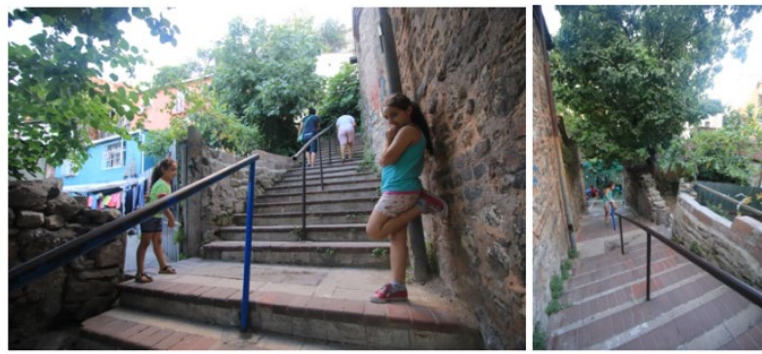

Resim 11. Merdivenlerde oyun - sosyal paylaşım, Merdivenli Mektep Sokak, Temmuz 2019 (Gül Yücel Arşivi)

\section{Tartışma ve Sonuç}

Fatih - Merdivenli Mektep Sokak, Beyoğlu - Hacı Ali Sokak ve Üsküdar Yeni Dünya Sokak'ın sokak niteliği kazandığı başlangıç yıllarında sosyal mekân olma özelliği olmadığını söylemek mümkündür. Günümüzde ise İstanbul'un zaman içindeki gelişimi ile kentin içinde farklı biçimde görünür olmuş ve bulunduğu konumun dışından da ilgi çeker duruma gelmişlerdir. $\mathrm{Bu}$ artan ilgide, seçilen merdivenli sokakların tarihi kent dokusu içerisinde yer almasının önemi olduğu kabul edilebilir. Fener-Balat semtinin son dönemde ilgi merkezi olması, Merdivenli Mektep Sokak'in da bu anlamda 
kullanılırlığını arttıran bir nedendir. Bu artışta ayrıca çevresindeki tarihi dokunun varlığı ve rotanın bağlandığı yapıların önemi olduğunu belirtmek doğru olacaktır. Merdivenli sokakların, fiziksel koşulları iyileştirilerek ve bölge halkı ihtiyaçları ve eğilimleri analiz edilerek kamusal kent hayatına kazandırılmasının, kente katkılarına ilave olarak kentliye de başta aidiyet hissinin güçlendirme gibi olumlu etkileri olmaktadır. İncelenen üç merdivenli sokak için bazı ortak noktalar tespit edilmiştir.

- Sayıca fazla dinlenme noktası; geniş sahanlıklar ve ticari amaçlı kullanılan zemin katlar sayesinde geçirilen vaktin uzun sürece yayılabilmesinde etkili olmaktadır.

- Merdivenli sokakta yer alan ağaç ve merdivenlerin ortalarında ya da kenarlarında peyzaj çalışması yapılmış olması, görsel olarak kentliyi tatmin etmesinin yanı sıra, yazın gölge yapması ve serinlik oluşturması açısından etkili olmaktadır.

- Merdivenlerin güzergahlarında tarihi binaların ve meydanın bulunması cazibe merkezi haline gelmesinde etkili olmaktadır.

- Kültür yapılarının merdivenlerin yakın çevrelerinde veya sokak güzergahında bulunması bu merdivenlerin yoğun olarak ziyaret edilmesinde etkili olmaktadır.

- Merdivenlerin sık kullanılır duruma gelmesi ile, merdivenleri çevreleyen bahçe duvarlarında duvar resimleri yapılmış, sokak hayvanları bakım ve yaşamları için birtakım malzemeler konulmuş ve sosyal hayatı besleyen bu faaliyetler neticesinde sokakların sosyal mekân olarak kullanılırlığı artmıştır.

- Sosyal ağlarda daha görünür hale gelen merdivenli sokakların artan popülaritesi ile kullanılırlığı doğru oranda artmıştır.

Kent içerisinde merdivenler iki farklı kotu bağlayan bir kent bileşeni olmasının yanı sıra kent için farklı sorumluluklar da üstlenmektedir. Dünya üzerinde merdivenli sokaklar sosyal olarak turistlerin ve kentte yaşayan kentlinin paylaşımlarda bulunduğu, farklı kültürel aktivitelerle etkileşime geçtiği ve sosyal deneyimler kazanabildiği mekanlar olmuşlardır. Bu çalışma kapsamında araştırılan ortak veriler ışığında, sanatçılar için malzeme olarak kullanılan, fotoğraf çekmek için özellikle ziyaret edilen, çevresinde bulunan peyzaj, manzara ve tarihi yapı ile kentlide dinlenme ve buluşma yeri olarak özellikle tercih edilen merdivenler, kent insanını kent ile etkileşime geçiren kente ya da bölgeye aidiyetini güçlendiren önemli şehir bileşenleridir. 


\section{Extended Abstract}

\section{Factors Affecting the Formation of Social Space In the Step Streets and Evaluation For Three Examples From Istanbul}

\author{
İlke Ciritçi \\ ORCID: 0000-0002-1492-0727
}

Gül Yücel

ORCID: 0000-0003-3722-6479

Life styles, mutual exchanges, activities and achievements that develop in urban spaces, in a sense, shape the quality of the urban space. The successful use of the streets as an urban space, functional, visually and psychologically, is possible with a creative design that is suitable for the lifestyle of the region, by correctly determining the needs, using environmental data correctly. The step streets in the historical districts come into prominence in parallel to the intensive use of the historical areas of the city, as places where the citizens interact socially and share their culture at certain times of the day. The fact that the step streets selected within the scope of the study are located at important points of the city is important for comparison. For this reason, especially the step streets under research are from the Fatih district (Merdivenli Mektep Street), Beyoğlu district (Hacı Ali Street) and Üsküdar district (Yeni Dünya Street), which are the leading historical districts of Istanbul.

To analyze the unique structure of the step streets, which have the potential to be a social space of Istanbul, is aimed for the study, in which qualitative research method is used. Data were obtained by literature research, field observation, documentation and evaluation methods. Within the framework of the findings obtained, the contributions of the step streets to the environment and lifestyle are examined. Physical characteristics, strengths and weaknesses, preferences and usage trends of the step streets as social spaces were investigated based on the data obtained from the field.

As digital technology becomes portable, so do people's means of expressing themselves. Reporting the situation and location shared on social networks 
constitutes a new culture that has turned into self-attraction and common visual speech. The level of sharing on social media can be used as preliminary information in evaluating the step streets in terms of social use. For this reason, in the study, the existence of the step streets as a social space and participation of step streets in urban life were evaluated through the user shares regarding their visibility on social media. The visibility of the step streets on social media was investigated through the photo and video sharing application "Instagram". Data on social media visibility has been taken into account according to the results of the screening for the first quarter of 2020 for each step street.

The step streets selected within the scope of the study are examined in terms of accessibility, efficiency, comfort and image-aesthetics, among the parameters White (2000) determined as four basic features that make the public space successful. The accessibility parameter is the determination of the location of the step streets in terms of location, the state of being central; The comfort parameter is examined by evaluating the physical and environmental properties of the step streets, the evaluation of the visibility obtained in social media with the activities carried out on the street with the activity parameter, and the evaluation of the whole physical properties of the aesthetic parameter.

Buildings and garden walls form the boundaries of Hacı Ali Street, Yeni Dünya street and Merdivenli Mektep Street. There are trees and railings on all three step streets and they are all renovated. When the step materials were examined, artificial stone was used in the stairs of each step street, but unlike the other two streets in the Yeni Dünya Street, natural stone was used instead of artificial stone in its risers, and it can be mentioned that there is partially original material. In all three step streets, there are historical buildings, landscapes, squares, murals and pets. Although all three step streets have a historical city view, the sea view is only available on Yeni Dünya Street.

Some common points have been identified for the three step streets studied.

- High in number rest points; Thanks to the wide landings and the ground floors used for commercial purposes, it is effective in spreading the time spent for a long time.

- Landscaping in the middle or sides of step streets is effective in terms of creating shade and coolness for high temperature of summer, as well as visually satisfying the citizen.

- The existence of historical buildings and the square on the location of the stairs is effective in making it a center of attraction.

- The existence of cultural buildings of the step street environment or on the step street location, is effective in visiting these stairs intensively. 
- As it became frequently used by the residents and visitors from outside the neighborhood, murals were made on the garden walls surrounding the stairs, some materials were placed for the care and lives of street animals, and as a result of these activities that feed the social life, the use of the streets as social spaces has increased.

- With the increasing popularity of step streets, which have become more visible in social networks, their usability has increased.

Step Streets in the city are not just an urban component connecting two different levels. It also takes on different responsibilities for the city. Step streets in the world are the places where tourists and city dwellers share socially, interact through different cultural activities and gain social experiences in the city. In the light of the common data researched within the scope of this study, the step streets, which are used as materials for artists, especially visited for photographing, and especially preferred as a resting and meeting place for the citizens with the landscape and historical structure around, they are important city components that strengthen the relation of the city.

\section{Kaynakça/References}

9.İstanbul Bienali Kitapçığı (2005). Ofset Yapımevi, 234-237, İstanbul.

Aksu, Ö.V. (2014). Kentsel dış mekânlarda merdiven tasarımlarının Trabzon Kenti örneğinde irdelenmesi. Kastamonu Üniversitesi, Orman Fakültesi Dergisi, 14(1), 7992.

Annaloro, A. (2013). A historic staircase in Caltagirone, Sicly used as a backdrop for light and flower festivals. https://www.thisiscolossal.com/2013/08/caltagirone-light-andflowers/ 15 Nisan 2021 tarihinde erişildi.

Aytar, İ. (2013). Karaköy'ün mekânsal belleği. Karaköy Çalıştayı, İstanbul Yeni Yüzyıl Üniversitesi Yayınları, 23-41.

Baran, B. (2006). Galata Hamamları ve Kılıc, Ali Paşa Hamamı koruma önerileri.Yüksek lisans tezi. Yıldız Teknik Üniversitesi Fen Bilimleri Enstitüsü, http://dspace.yildiz.edu.tr/xmlui/handle/1/11260 adresinden erişilmiştir.

Ciritci, İ. (2019). Markiz: Beyoğlu'nun Mekân-Kültür Artikülasyonu Üzerine. IAPS: Culture and Space Konferansinda sunulan bildiri, İstanbul.

Coco, P. (2019). Dali. https://fineartamerica.com/featured/dali-paul-coco.html adresinden erişilmiştir.

Conclin, T. R. (2012). Street art, Ideology and public space. Portland State University, Dissertations and Theses, Amerika, https://core.ac.uk/download/pdf/37772385.pdf adresinden erişilmiştir.

Çakı, F. (2017). Aidiyet ve mekân olarak sokaklar: Balıkesir örnek olayı çerçevesinde bir tipoloji önerisi. Çekmece İZÜ Sosyal Bilimler Dergisi, 5(10-11), 25-54.

Ekoyapı. (2013). Onlar sokak bizim dedileri. https://www.ekoyapidergisi.org/221-onlarsokak-bizim-dediler.html adresinden erişilmiştir. 
Ergen, Y. B. (2011). Anadolu'da kültür birlikteliğinin konut ve kentsel yerleşim dokusuna etkisi. Kent ve Toplum, Mayıs-Haziran: 85-102.

Italianways. (2020). The staircase of Santa Maria Del Monte: Maiolica and Fire. 17.11.2014 tarihinde https://www.italianways.com/the-staircase-of-santa-maria-del-montemaiolica-and-fire/ adresinden erişilmiştir.

İnceoğlu M. ve Aytuğ A. (2009). Kentsel mekânda kalite kavramı. Megaron4(3): 131146

Jobson, C. (2013). New Origami Street Art in Angers, France by Mademoiselle Maurice. https://www.thisiscolossal.com/2013/06/new-origami-street-art-in-angers-franceby-mademoiselle-maurice/

Marzagao, M. (2020). Escada acima, escada abaixo... faz bem às pernas. http://www.camaraportuguesa-rj.com.br/escada-acima-escada-abaixo-faz-bem-as-pernas/

Murat, E. (2020). Beyoğlu sokaklarında merdivenler tabloya dönüştü. DHA.https://www.dha.com.tr/istanbul/beyoglu-sokaklarinda-merdivenler-tabloya-donustu/haber-1791154

Oğan, A. (1950). Yeniden kurulan Berketzade çeşmesi. Türkiye Turing ve Otomobil Kurumu Bülteni, 15 Eylül 2020 tarihinde http://earsiv.sehir.edu.tr:8080/xmlui/bitstream/handle/11498/3010/001580503010.pdf?sequence=3 adresinden erişildi.

Özbayraktar, M. (2015). Kolektif bellek, kent belleği ve sokaklar: İmit Merkez Geleneksel Sokakları. Uluslararası Gazi Akça Koca ve Kocaeli Tarihi Sempozyumu Bildirileri : 15551569

Öztürk, K. (2008). Üsküdar Harem semti'nin tarihi gelişimi. Marmara Üniversitesi Türkiyat Araştırmaları Enstitüsü, Yüksek Lisans Tezi, İstanbul

Philadelphia Museum of Art. (2005). Exhibitions. https://philamuseum.org/exhibitions/2005/83.html

Philadelphia Museum of Art. (2020). Mainpage. https://philamuseum.org/

Tatlıdil, E. (2009). Kent ve kentli kimliği: İzmir Örneği. Ege Akademik Bakış / Ege Academic Review 9(1), 319-336.

Tuna, B., (1999). 12 Şubat 1999 Hürriyet İstanbul Gazetesi haberi. İstanbul.

Uzgören, G. ve Erdönmez M.E. (2017). Kamusal açık alanlarda mekân kalitesi ve kentsel mekân aktiviteleri ilişkisi üzerine karşılaştırmalı bir inceleme. Megaron 12(1), 41-56.

Uzundumlu, Ö. (2015). Bir İletişim Unsuru Olarak Sosyal Selfie Uygulamaları. Atatürk İletişim Dergisi, 8, 227-248.

Sokakbizim. (2020). Fotoğraf.https://www.instagram.com/sokakbizim/?hl=tr

Stabiner, K. (2016). Fotoğraf. https://www.nytimes.com/2016/10/23/travel/roman-holiday-film-rome-italy-hepburn-peck.html

Şehir haritası. (2020). İstanbul büyükşehir Belediyesi şehir haritası. https://sehirharitasi.ibb.gov.tr/

Yücel G., Ciritci İ. (2020). Merdivenli sokaklar için çoklu afet risk değerlendirme ve erişebilirlik : İstanbul örneği. Megaro, 15(2): 254-269

Yücel, N. N. (1996). Balat'ta Tarihi Çevre Koruma Projesi. İstanbul Teknik Üniversitesi Fen Bilimleri Enstitüsü Yüksek Lisans Tezi, İstanbul. https://polen.itu.edu.tr/xmlui/handle/11527/17096 
Zusmann, K. (2020). Spanishs steps. https://rome.us/squares-and-fountains/spanishsteps.html\#: :text=The\%20Spanish\%20Steps\%20is\%20an,Italian\%3A\%20Piazza\%20di\%20Spagna)

White, W.H. (2000). The social life of small urban spaces. Z.P. Anthony M. Orum Common Ground, Readings and Reflections on Public Space, New York: Routledge 32-39.

Wikipedia. (2020) Rocky Step. https://en.wikipedia.org/wiki/Rocky_Steps

Wikipedia. (2020). Spanish Steps. https://en.wikipedia.org/wiki/Spanish_Steps 